\title{
The Presidential Indian Peace Medal
}

\author{
By Wirliam E. (BrLl) Yeast
}

It was at one time the custom of the United States War Department to present peace medals to Indian chieftains upon the conclusion of treaties of peace. These medals had on one side of them the date and bust of the president at the time of the treaty, and on the other side a picture of an Indian chief talking with a pioneer in front of a cabin. At the bottom there was an olive wreath encircling a calumet and tomahawk, and at the top the word "peace."

One of these medals which is seen on the following page, was secured by the author from a trader during a recent trip into Winnebago Indian Country. It was issued by President Grover Cleveland in 1885 and is readily identfied as Winnebago because of the type of beadwork on the necklace. This medal represents a chaotic period in American Indian history.

On February 27, 1885, five days before Cleveland was inaugurated president, a tract of Indian land consisting of nearly one-half million acres was thrown open for settlement by President Chester A. Arthur. This permitted the acquisition by white men of a great part of the Winnebago and Crow Creek Reservations in Dakota Territory, and was in direct violation of a former treaty.

Cattlemen who desired the land for themselves, had complained to President Arthur that the "lazy" Indians did not need the vast grasslands and had accused them of every evil act that could be committed by savages. The President was then persuaded to allow illegal use of the Indians' land.

Soon, after Cleveland had taken office, friends of the Indians appealed to him to correct the injustice and he ordered an immediate investigation which proved Arthur had been wrong. It was found that Arthur had in the past often condoned such illegal acts which placed many hardships upon the Indians of the northern tribes.

On April 17, Cleveland issued a warning in the form of a proclamation to all people concerned with these infractions, 


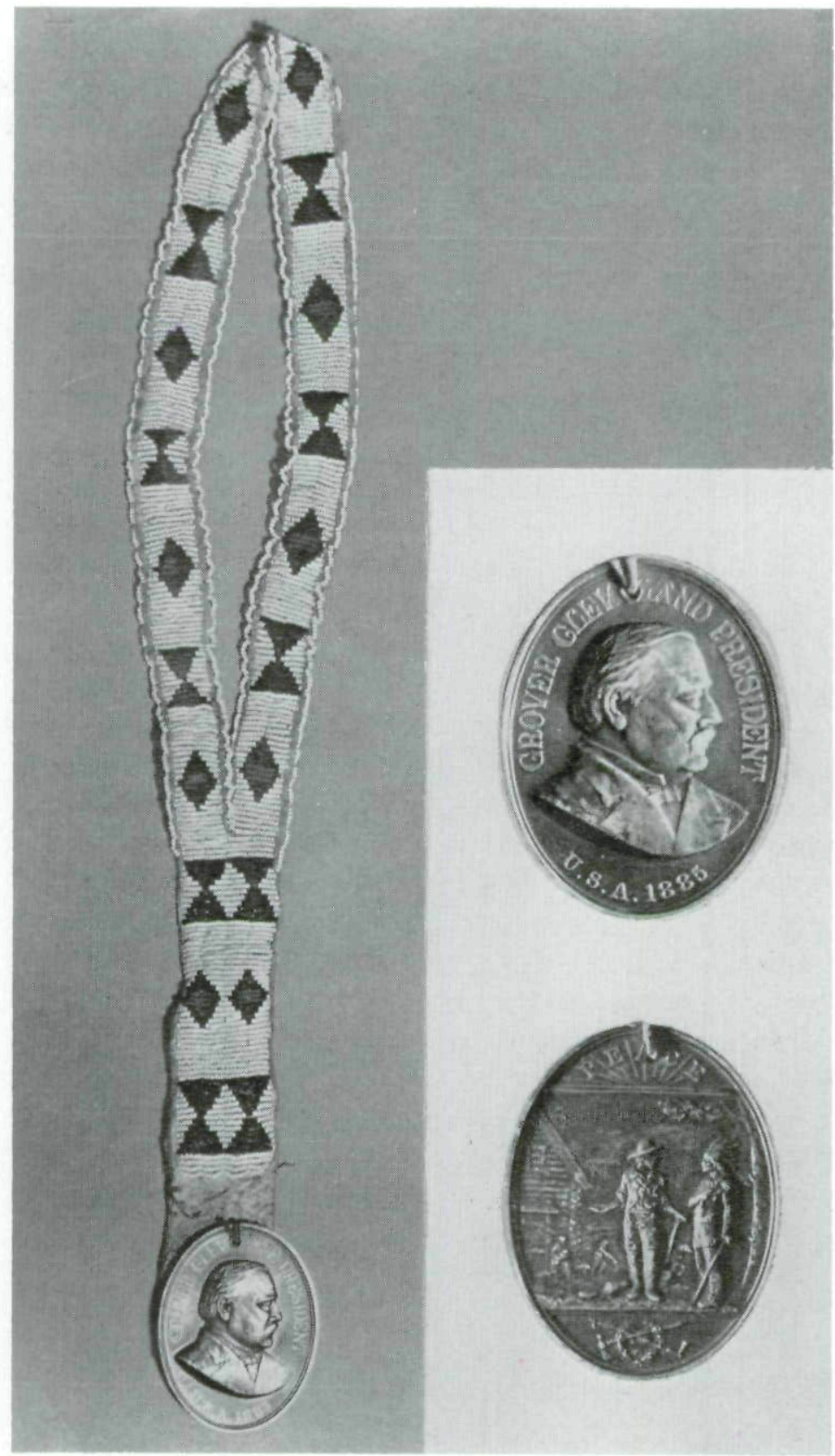


and sent General Phil Sheridan west to collect the facts and to appease the justifiably irate and hostile tribes whose land had been so abruptly taken from them. Sheridan offered the "Great White Father's" apologies for the injustices they had suffered.

The General carried with him Presidential Indian Peace Medals which he presented to the Chiefs and Tribal Council leaders in hopes that the Indians would believe in the promises of the new "Great White Father." The medals did have enough of a soothing effect for Sheridan to complete his investigating and he found the white men to be entirely wrong and guilty of flagrant violations of the law.

The majority of the chiefs were so favorably impressed with the Peace Medals that they bored holes in them and wore them about their necks on beautifully beaded necklaces. A few of these are still in existence.

This, however, is not the end of the story, for the investigation by Sheridan and Secretary of the Interior, Lucius C. Lamar, turned up many other grave injustices. These included broken treaties, hostilities against the Indians, and the use of four million acres of grazing lands at an annual rental of one to two cents per acre, with the Indians liable for the loss of all cattle, which was deducted from the rental fees.

On July 23, 1885, Cleveland issued a proclamation giving the white men 40 days to clear the Indians' land of their cattle. More than 200,000 head were driven out onto overcrowded ranges to face one of the worst winters in history. More than four-fifths of the cattle died.

Cleveland saw to it that his orders were carried through. It is even said that one of his best friends lost a quarter of a million dollars due to the proclamation. Steps were taken to avert any outbreaks of hostilities which might have occurred in the aftermath.

So ... men of courage took a righteous stand in behalf of a few against many.

References; GROVER CLEVELAND, by Allan Nevins. 
Copyright of Annals of Iowa is the property of State of Iowa, by \& through the State Historical Society of Iowa and its content may not be copied or emailed to multiple sites or posted to a listserv without the copyright holder's express written permission. However, users may print, download, or email articles for individual use. 